\title{
Sexual Fluidity in Mohsin Hamid's Exit West
}

\author{
Md. Al Walid (Corresponding author) \\ Department of English, Jashore University of Science and Technology, Bangladesh \\ Email: md.alwalid.eng@just.edu.bd
}

Received: $27 / 08 / 2020$

Accepted: 15/12/2020

Published: 01/01/2021

Volume: 2 Issue: 1

How to cite this paper: Walid, M. A. (2021). Sexual Fluidity in Mohsin Hamid's Exit West. Journal of Critical Studies in Language and Literature, 2(1), 13-21

DOI: https://doi.org/10.46809/jcsll.v2i1.48

Copyright ( 2020 by author(s) and Global Talent Academy Ltd. This work is licensed under the Creative Commons Attribution International License (CC BY 4.0).

http://creativecommons.org/licenses/by/4.0/

\section{(c) (9)}

\begin{abstract}
Exit West by Mohsin Hamid propagates the reflection of a war-torn city and subsequent challenges faced by two asylum seekers. But sexual fluidity may appear as another key concern of the novel. This paper analyses the traits of sexual fluidity in Nadia, one of the protagonists of the novel experimenting her situation-dependent flexibility in sexual responsiveness. Nadia, in the beginning, is though found as a heterosexual adult girl, over time she becomes sexually fluid. Again, in the last phase of her life, she returns to meet Saeed, her first noteworthy lover with whom she shares the most crucial part of her life in home and abroad. This shifting of sexual attraction elevates questions about her sex/sexual preference broadly considering the concept of nonexclusive attractions and behaviours. Finally the paper comes to a decision how different concepts of sexuality are motivated by cultural, biological, and psychological constructs.
\end{abstract}

Keywords: Sexual Fluidity, Non-Exclusive Attractions and Behaviours, Situation-Dependent Flexibility

\section{Introduction}

Exit West (2017) is a novel concerned about militancy, migration and slashed reality. Saeed and Nadia, the protagonists of the novel meet at "an evening class on corporate identity and product branding" (Hamid, 2017, p. 1). Saeed and Nadia are much progressive in comparison to their societal context, seems Nadia serves in an insurance company and Saeed in an advertisement agency. Nadia from a decent and conservative background dares to live alone, rides a motorbike and importantly does not pray living in a complete contrary situation. Saeed, son of a university professor seems secular and falls in love with Nadia probably for her nonconformist attributes. Their city possibly situated in Pakistan starts filling with refugees. Meanwhile the cruelty of militants reaches at its peak. After the death of Saeed's mother because of a severe militant attack, Saeed and Nadia through a magical door moves to Europe and consequently reach at Mykonos at first, then in London and after that in San Francisco. They also experience their relationship's ups and downs in the meantime.

There has been very less amount of scholarly works done on 'sexual fluidity' and none still has discussed it with reference to Mohsin Hamid's Exit West. This paper examines Nadia's relationship with Saeed, the musician- her first lover and her emotional and sexual attachments with some other girls over time. Taking into account, sexual fluidity as a natural norm, the research work investigates its impact on the behavior of sexually fluid people. Thus, it aims to place the state of the sexually fluid people in a society in the light of Exit West.

This paper functionally is an analytical research following qualitative method. The paper intentions to reconfigure traditional concept of sex, sexual orientation, and sexual behavior and studies the viability of sexual fluidity with reference to 
Nadia's relationship making in Mohsin Hamid's Exit West. Lisa M. Diamond's concept of 'Sexual Fluidity' in her Sexual Fluidity: Understanding Women's Love and Desire (2009) mainly forms the theoretical framework to defend the argument of the paper. First the paper monitors the definition of sexual fluidity, and then it displays the non-exclusive attractions and behaviours in the words of Diamond. Finally how sexual fluidity and non-exclusive attractions and behaviours are so related to Nadia's attitude is discussed in the paper.

\section{Sexual Fluidity}

The world from unknown time being has normalized heterosexuality even though the existence of homosexuality is prevalent almost from the same time. Heterosexuality mostly for the purpose of regeneration is prioritized. On the other hand, homosexuality is always categorized as abnormal. According to Kitzinger, "Once upon a time, the story goes, researchers thought that homosexuals were sick and perverted." It easily can be perceived that how much humiliation they have to tolerate then. He added, "This was because they were blinded by religious prejudice and trapped by the social conventions of their time: their research lacked present-day sophistication and objectivity." So, at that time, religious prejudices and the dominant social concept of sexuality manufactured by society shut the scope of natural homosexuality. Gradually scholarly progress makes people more sophisticated in general what sprouts the room to nurture the unconventional issues like queer, homosexuality etc. Again, he said, "Now, in our sexually liberated age, with the benefit of scientific rigour and clear vision, objective up-to-date research demonstrates that lesbians and gay men are just as normal, just as healthy, and just as valuable members of a pluralistic society as are heterosexual people." (Kitzinger, 1987, p. 8) Finally in the last segment of twentieth century, scholars dare to dream of a pluralistic society. This acceptance of the former unusual attribute of sexuality further opens the scope of more radical recent day's sexuality- sexual fluidity. The age of sexual fluidity is not less in comparison to other forms of sexuality but due to the several social constructs, it has been neglected for long.

At present because of scientific progress and the voices for humanity, the acceptance of homosexuality has increased significantly. But it also has opened the floor of diverse possibilities of sexuality irrespective of their biological sex. To understand the differences, sexual fluidity can help the critiques and readers. Diamond explains,

Sexual fluidity, quite simply, means situation-dependent flexibility in women's sexual responsiveness. This flexibility makes it possible for some women to experience desires for either men or women under certain circumstances, regardless of their overall sexual orientation. In other words, though women - like men-appear to be born with distinct sexual orientations, these orientations do not provide the last word on their sexual attractions and experiences. Instead, women of all orientations may experience variation in their erotic and affectional feelings as they encounter different situations, relationships, and life stages." (Diamond, 2009, p.3)

At first it looks a bit weird to many but the fact can be analysed from anthropological point of view. If the idea can be explored a bit more, it can be found that

The anthropologist Evelyn Blackwood made an observation in her extensive review of female same-sex sexuality across non-Western cultures, underscoring the limitations of the Western notion of fixed sexual orientations. These perspectives were consistent with a broad class of social constructionist models of sexuality, which posited that sexual identities did not exist as fixed types but were created and given meaning through social interactions and cultural ideologies." (Diamond, 2009, p. 5)

To understand this "an example can be given. The actress Cynthia Nixon of the HBO series Sex and the City developed a serious relationship with a woman in 2004 after ending a fifteen-year relationship with a man.” (Diamond, 2009, p. 1) More words can be added in this regard. The famous American poet Adrienne Rich before the expansion of the idea of sexual fluidity has discussed fluidity's explicit application to female sexuality. She first has brought into light this with political perspectives:

Rich argued that women throughout history and across a variety of different cultures had always managed to form intimate, emotionally primary ties to other women, despite the persistent efforts of male-dominated societies to rigidly channel them into heterosexual reproduction. Rich argued that all intense bonds between women, even if they were not explicitly sexual, occupied a "lesbian continuum" that ranged from purely emotional relationships to sexual liaisons. This model suggested that regardless of whether a woman currently experienced clear-cut same-sex desires, she maintained a capacity for diverse forms of same-sex intimacy and eroticism." (Diamond, 2009, p. 5)

To sum it up, it can be said that sexual fluidity may be regarded as a further element of a woman's sexuality that functions in concert with sexual orientation to impact how her other attributes like attractions, fantasies, behaviors, and affections are experienced and expressed over the life course. Fluidity comes up with a notion that some women are gifted of a wider diversity of sensual feelings and experiences. The intensity of it lies in a level that is beyond our prediction on the basis of their self-described sexual orientation alone.

\section{Nonexclusive Attractions and Behaviours}

In the article 'The Psychogenesis of a Case of Female Homosexuality', Freud asserts "homosexuality is just as common among women as men, but it is not illegal, it is not felt to be socially subversive, it is far less conspicuous, and, although he 
does not say this, perhaps we wish to avoid thinking about the active sexuality of women.” (Budd, 2005, p. 234) Women's homosexuality thus is ignored for long in systematic study but it can be of diverse characteristics. That is why the clarification of nonexclusive attractions and behaviours is needed to let people know. In the words of Diamond,

By speaking of nonexclusivity, I intentionally sidestep questions about what bisexuality "really" is, who "has" it, and whether some types are more authentic or intrinsic than others. My goal, instead, is to describe and understand the phenomenon of nonexclusivity in all its forms, and to explore their implications for female sexual fluidity. The downside to using the term "nonexclusivity" is that some people might associate it with infidelity, since the term "exclusive" is often used to refer to monogamous relationships. Let me reiterate that this is not the usage I intend. Even in the context of sexual behavior, I use "nonexclusive" simply to describe a woman who has pursued sexual behavior with both women and men over the course of her own sexual history, not at the same moment in time. I have been troubled enough by potential misinterpretations of the term "nonexclusivity" to have spent a good deal of time searching for alternatives, but to no avail. So I continue to use this term." (Diamond, 2009, p. 96)

To understand sexual fluidity, nonexclusive attractions and behaviours play a key role. Here in Exit West, Nadia's sexual attractions and behaviours whether is nonexclusive is investigated to understand her sexual fluidity. The context of Nadia's relationship with Saeed is first discussed. Then her relationship with two other women have been analysed to understand her nonexclusive attraction and behaviours over the course of her own sexual history. This paves the way to understand sexual fluidity in Hamid's Exit West.

\section{Nadia and Sexual Fluidity}

The novel introduces us with heterosexual relationship almost from the beginning. "When Saeed's parents first met they were the same age as were Saeed and Nadia when they first did." (Hamid, 2017, p. 10) The way dialogues move on in the novel envisages heterosexuality as a normative practice. "They met at the cinema, during the interval of a film about a resourceful princess. Saeed's mother spied his father having a cigarette and was struck by his similarity to the male lead in the movie." (Hamid, 2017, p. 10) Men's traditional manly attributes have been reasoned to fall in love here in the novel. "Saeed's father styled himself after the popular film stars and musicians of his day, as did most of his friends. But Saeed's father's myopia combined with his personality to give him an expression that was genuinely dreamy, and this, understandably, resulted in Saeed's mother thinking he not merely looked the part, but embodied it. She decided to make her approach." (Hamid, 2017, p. 10) Wondering about Saeed's parents' relationship, it is found that it is extremely heterosexual trait. "Saeed's parents did not have sex until their wedding night. Of the two, Saeed's mother found it more uncomfortable, but she was also the more keen, and so she insisted on repeating the act twice more before dawn. For many years, their balance remained thus. Generally speaking, she was voracious in bed. Generally speaking, he was obliging." (Hamid, 2017, p. 12) In later days of their life, the attraction for each-other subsides. This also brings the question of viability in sexual desire for decades. "Saeed's mother would sometimes wonder whether he did this out of genuine desire or habit or simply for closeness." (Hamid, 2017, p. 12)

The grown up environment of Nadia has accelerated her opposite sex attraction, can be said. While she comes in touch with Saeed, she "watched Saeed's features." (Hamid, 2017, p. 21) In their first meetings it's observed that they feel intensely for each-other physically though Saeed always would resist him to have sexual intercourse. While Nadia invites him at home "Saeed seemed surprised and extremely excited when she suggested he come." (Hamid, 2017, p. 22) Nadia though warns him but her gaze towards him proves that Saeed should transgress the social boundary of not to do sex. "Nothing is going to happen,' she explained. 'I want to make that clear. When I say you should come over, I'm not saying I want your hands on me.' 'No. Of course."' (Hamid, 2017, p. 22)

Nadia though from a conservative family but her freedom of choice is sharper. She did have a relationship with a musician earlier. Their dating was full of enthusiasm. As in the text, "She had, as was by then usual for her, been wearing her black robe, closed to her neck, and he had, as was by then usual for him, been wearing a size-too-small white T-shirt, pinned to his lean chest and stomach, and she had watched him and he had circled her, and they had gone to his place that night, and she had shuffled off the weight of her virginity with some perplexity but not excessive fuss." (Hamid, 2017, p. 30) Nadia's open mindedness is strongly proved in their further meet ups. "She suspected he had many other women. She did not want to inquire. She appreciated his comfort with his own body, and his wanton attitude to hers, and the rhythm and strum of his touch, and his beauty, his animal beauty, and the pleasure he evoked in her. (Hamid, 2017, p. 31) Even after this she dared meeting him again for a friendly farewell. "Nadia at first thought there was no need to say goodbye, that saying goodbye involved a kind of presumption, but then she felt a small sadness, and knew she needed to say goodbye, not for him, for she doubted he would care, but for her. And since they had little to say to one another by phone and instant message seemed too impersonal, she decided to say it in person, outdoors, in a public place, not at his messy, musky apartment, where she trusted herself less, but when she said it, he invited her up, 'for one last time', and she intended to say no but actually said yes, and the sex they had was passionate farewell sex, and it was, not unsurprisingly, surprisingly good. (Hamid, 2017, pp. 31-32) This final goodbye sex with him cannot be imagined being in such a prejudiced country. So while Nadia is grown up enough there's no clue of homosexuality in the text. The first two relationships of Nadia are highly heterosexual as if electron has attracted proton. 
Nadia's relationship with Saeed lasts long. In their first dates "He (Saeed) made her laugh, once, then again, he made her skin burn and her breath shorten with the surprised beginnings of arousal, he became present without presence, and she did much the same to him. Soon a rhythm was established, and it was thereafter rare that more than a few waking hours would pass without contact between them, and they found themselves in those early days of their romance growing hungry, touching each other, but without bodily adjacency, without release. They had begun, each of them, to be penetrated, but they had not yet kissed." (Hamid, 2017, pp. 36-37) Their code of ethics created by society most of the time would keep them aloof from further attachment. They often would come closer and share romantic moments. "As he sat he felt the outside of her thigh, firm, against his, and she felt the outside of his, likewise firm, against hers. She said, 'Aren't you going to take that off?' She meant the black robe, which he had forgotten he was wearing, and he looked down at himself and over at her, and smiled, and answered, 'You first.' She laughed. 'Together, then.'” (Hamid, 2017, p. 42)

From outer layer the relationship between Nadia and Saeed seems tiptop but a mental gap between the two appears gradually, and the author or the narrator weaves in the plot of a future coming homosexuality or otherwise sexual fluidity. After passing a whole night with much emotional attachment without having sex, Nadia goes to have a bath. "She stood naked, as she had been born, and put on her jeans and T-shirt and sweater, as she did when alone at home, and then put on her robe, ready to resist the claims and expectations of the world, and stepped outside to for a walk in a nearby park that would by now be emptying of its early-morning junkies and of the gay lovers who had departed their houses with more time than they needed for the errands they had said they were heading out to accomplish." (Hamid, 2017, p. 45)

In spite of some mismatches Saeed and Nadia give the impression of a happy couple. As the city environment worsens due to extreme rise of militant activities, they meet during day at a place where they feel comfortable and can exchange some private moments as well. "Sometimes he stroked the inside of her thigh and she placed her palm on the zip of his trousers, but only briefly, and rarely, in the gaps when it appeared waiters and fellow diners were not looking, and they tormented each other in this way, since travel between dusk and dawn was forbidden, and so they could not be alone without sound spending the entire night, which seemed to her a step well worth taking, but to him something they should delay, in part, he said, because he did not know what to tell his parents, and in part because he feared leaving them alone." (Hamid, 2017, p. 51)This adverse situation has played as a catalyst to intensify their feelings. As they no longer meet in home at night, they become dependent on ghost communication tools; phone, message. It showcases the platonic tune of their affair and seemingly, to be platonic, the relationship should be heterosexual.

Additionally, the readers though get sure that they are in love but Nadia even after passing some so intimate moments with Saeed does not feel certainly whether she is in love with him. "Saeed was certain he was in love. Nadia was not certain what exactly she was feeling, but she was certain it had force." (Hamid, 2017, p. 52) But this did not change their continuity of relationship. Further, it's found that their intensity of loves augments over days. As in the novel, "She met him in a nearby café since it was too risky for her to drop a robe into the street by day, or for him to change outdoors, and so he pulled it on in the café's bathroom while she paid the bill and then with his head covered and eyes on the ground, followed her into her building, and once upstairs and inside they soon slipped into her bed and were nearly naked together and after much pleasure but also what she considered a bit excessive a delay on his part she asked if he had brought a condom and he held her face in his hands and said, 'I don't think we should have sex until we're married.'

And she laughed and pressed close.

And he shook his head.

And she stopped and stared at him and said, 'Are you fucking joking?'

For a second, Nadia was seized by a wild fury but then as she looked at Saeed he appeared almost lethally mortified and a coil loosened in her and she smiled a little and she held him tight, to torture him and to test him, and she said, surprising herself, 'It's okay. We can see."' (Hamid, 2017, p. 53) The struggle of sexual interaction continues which cuts a deep ache to Nadia's mind.

Meanwhile Nadia continues to face the adverse effect of society relate to sexual abuse. She visits a bank for a transaction but there she is molested by an unknown guy while she is on the queue. "There in the unruly crowd she was groped from behind, someone pushing his hand down her buttocks and between her legs, and trying to penetrate her with his finger, failing because he was outside the multiple fabrics of her robe and her jeans and her underclothes, but coming as close to succeeding as possible under the circumstances, applying incredible force, as she was pinned by the bodies around her, unable to move or even raise her hands, and so stunned she could not shout, or speak, reduced to clamping her thighs together and her jaws together, her mouth shutting automatically, almost physiologically, instinctively, her body sealing itself off, and then the crowd moved and the finger was gone and not long afterwards some bearded men separated the mob into two halves, male and female. (Hamid, 2017, pp. 59-60) This kind of behaviour from her fellow people gives her a very bad impression about her society's men. Nadia wants to overcome the traumatic experience in bank. She meets Saeed. Nadia in this regard follows Freudian defence mechanism. "Defenses" according to Freud "are the processes by which the contents of our unconscious are kept in the unconscious. In other words, they are the processes by which we keep the repressed repressed in order to avoid knowing what we feel we can't handle knowing." (Tyson, 2006, p. 15) Nadia mostly goes for 'denial', 'avoidance', 'displacement' and 'projection' to handle her present. Here, "denial' stands for "believing that the problem doesn't exist or the unpleasant incident never happened". (Tyson, 2006, p. 15) She tries to erase her immediate past experience through projecting it to some other activities. The next is 'avoidance'. Another key term "avoidance" means "staying away from 
people or situations that are liable to make us anxious by stirring up some unconscious—i.e., repressed-experience or emotion". (Tyson, 2006, p. 15) She attempts keenly to stay away from the memory of her molestation so that it cannot make her anxious. Then her emotions become dependent on "displacement" what means "taking it out on someone or something less threatening than the person who caused our fear, hurt, frustration, or anger" (Tyson, 2006, p. 15). Displacement is proved by her desire to meet Saeed just after the bad experience in bank. Finally she tries to project her emotions on Saeed. The meaning of "projection" is "ascribing our fear, problem, or guilty desire to someone else and then condemning him or her for it, in order to deny that we have it ourselves". (Tyson, 2006, p. 15) "They smoked a joint and listened to music and after a while Nadia tried again to make Saeed have sex with her, not because she felt particularly sexy but she wanted to cauterize the incident outside from the bank in her memory, and Saeed succeeded again in holding back, even as they pleasured each other, and he told her again that they should not have sex before they were married, that doing otherwise was against his beliefs, but it was not until he suggested she move in with his parents and him that she understood his words had been a kind of proposal." (Hamid, 2017, p. 61) As if to cauterize the bad experience she is throwing it on Saeed. Nadia's deep pain in mind thus is not mollified.

Sex however is obvious in Saeed and Nadia's relationship as they are having continuous close times together but, because of Saeed's moral code, it was not being done. Finally after the death of Saeed's mother, they final went for it. "The following night, or perhaps the night after that, Saeed entered Nadia's room and they were unchaste there for the first time. A combination of horror and desire subsequently impelled him back each evening, despite his earlier resolution that they do nothing that was disrespectful to his parents, and they would touch and stroke and taste, always stopping short of sex, upon which she no longer insisted, and which they had by now found ample means to circumvent." (Hamid, 2017, p. 80) But even after the sexual pleasure a subsequent melancholia continues because of the demise of Saeed's mother.

A kind of strange failure starts in Saeed and Nadia's relationship. To avoid the terror of militants they tend to migrate and consequently meet an agent. Even there Nadia faces an uncomfortable and disrespectful experience. "While they were having a conversation with the agent, Nadia had the sense he was extremely close to her, as if he were about to touch her neck, but she could not hear his breathing." (Hamid, 2017, p. 84) This can be interwoven with the further relationship with Saeed.

After migration in Mykonos, Nadia's latent homosexual trait comes into light. Nadia and Saeed have had an unpleasant experience there. They get injured. At that time she meets her first same-sex crush. "A partly shaved-haired local girl who was not a doctor or a nurse but just a volunteer, a teenager with a kind disposition, not more than eighteen or nineteen years of age, cleaned and dressed the wound, gently, holding Nadia's arm as though it was something precious, holding it almost shyly. The two women got to talking, and there was a connection between them, and the girl said she wanted to help Nadia and Saeed, and asked them what they needed. They said above all they needed a way off the island, and the girl said she might be able to do something, and they should stay nearby, and she took Nadia's number, and each day Nadia visited the clinic and she and the girl spoke and sometimes had a coffee or a joint together and the girl seemed so happy to see her. (Hamid, 2017, pp. 113-14) In the text, Sexual Fluidity we get that sexual orientation is not required for sexual fluidity. As in the text, "Does sexual fluidity mean that sexual orientation can be changed? No. It simply means that a woman's sexual orientation is not the only factor determining her attractions. A predominantly heterosexual woman might, at some point in time, become attracted to a woman, just as a predominantly lesbian woman might at some point become attracted to a man. (Diamond, 2009, p. 11) Diamond adds her observation that "Despite these experiences, the women's overall orientation remains the same." (Diamond, 2009, p. 11) Again we find,

People do not always have an exclusive preference for their own or the opposite sex. Sometimes they are attracted to their own and the opposite sex during the same period in time. Or they may live many years attracted to the opposite sex, but then change their interests to the same sex. Or they may dart around between opposite and same-sex partners with no discernible pattern. These "bisexual" patterns of sexuality are not uncommon. (Weinberg, Williams and Pryor, 1994, p. 4)

Weinberg, Williams and Pryor have the treated this apparently bizarre fact as "bisexual pattern" but to Diamond it's more non-exclusive behaviour which visualises one's sexual fluidity as we here, in Exit West, find in the character of Nadia.

Nadia and the volunteer girl's happy togetherness incline the tone of homosexuality. Though at this stage, it cannot be said surely whether it is situation dependent. This girl helps them to move further in a better place of Europe. Before the couple's departure, Nadia meets the girl and their interaction vibrantly seems homosexual affinity. "The girl wished them good luck, and she hugged Nadia tight, and Saeed was surprised to see what appeared to be tears in the girl's eyes, or if not tears then at least a misty shine, and Nadia hugged her too, and this hug lasted a long time, and the girl whispered something to her, whispered, and then she and Saeed turned and stepped through the door and left Mykonos behind. (Hamid, 2017, pp. 114-15) For Nadia the attraction can be said "nonexclusive'. As in the text, Sexual Fluidity, "I use "nonexclusive" simply to refer to the capacity to experience both same-sex and other-sex desires and behaviors, though not necessarily at the same point in time. Someone with nonexclusive attractions might have experienced only other-sex attractions up until adolescence, and then only same-sex attractions thereafter. Someone else might experience desires for both women and men concurrently. All that matters is that for that person, both types of desire are possible, in contrast to someone who has always been exclusively attracted to one sex or the other." (Diamond, 2009, p. 14) In Nadia's case the hypothesis is quite correct as she will be found in her mature age to have relationship with woman mostly. 
New place invites Saeed and Nadia the decay of their personal relationship. In London, Saeed feels alienated from the rest. Nadia tries to calm Saeed but his inner agony is not being relieved easily. "She smiled and moved to kiss him, and while her lips did touch his, his did not much respond. 'It's been for ever,' he said. 'This isn't our house."” (Hamid, 2017, p. 122) Some sociocultural factors do work in this case. As in the text, Sexual Fluidity, "I count myself among the growing number of social scientists who view sexual feelings and experiences as simultaneously embedded in both physical-biological and sociocultural contexts that require integrated biosocial research strategies. This is the perspective I take on sexual fluidity." (Diamond, 2009, p. 22) The further scope of homosexuality gets a chance to boost from this phase of life of Nadia as her impact on Saeed gradually decreases. Saeed's possessive words, she cannot tolerate. 'Don't tell me what I can do.' (Hamid, 2017, p. 122) This kind of words uttered by Nadia proves her dissatisfaction towards Saeed and the relationship. Saeed's sociocultural sphere made him thinking in such a way. "He looked stung by this comment, and also angry, and she was angry as well, and after he had bathed, and washed his clothes, which he did perhaps as a conciliatory gesture or perhaps because once he was cleansed of his own grime he too realized something of what she had realized, they slept on the slender single bed together without speaking, without touching, or without touching more than the cramped space demanded, for this one night unlike a couple that was long and unhappily married, a couple that made out of opportunities for joy, misery. (Hamid, 2017, p. 123) As in The Second Sex, "He is the transcendent, he soars in the sky of heroes; the woman crouches on the ground, under his feet; he enjoys measuring the distance separating him from her; from time to time, he raises her to him, takes and then rejects her; never does he lower himself toward her sphere of viscous darkness." (Beauvoir, 2010, p. 306) This domain of phallic syndrome strikes Nadia's mind. As a result, the struggle of their relationship continues. Further we get in the novel, "Let's agree to try harder not to speak shittily to each other,' she said. He smiled. 'Let's promise." (Hamid, 2017, p. 133) This kind of promise they did not feel previously in their life what again proves the futility of their relationship.

The incidents follow in the novel are escapist attitude from both side. Usually they would like to avoid each other but they also try to recover their former passionate relationship. In the words of narrator, "As they sat they would on occasion hold hands, and on occasion kiss, and once in a while feel the rekindling of an otherwise diminished fire and go to their bed and torment each other's bodies, never having sex, but never needing to, not any more, following a different ritual that still resulted in release." (Hamid, 2017, p. 139) Meeting country people gives Saeed pleasure whereas caused by previous abusive experiences by native people, Nadia cannot accept them. So escaping each other continues. They no longer enjoy their company in bed. "He did not press the point, but when Nadia brought her face close to his in bed that night, close enough to tickle his lips with her breathing, he was unable to muster the enthusiasm to bridge the tiny distance it would have taken to kiss. (Hamid, 2017, p. 150)

The on-going relationship between Saeed and Nadia as diminishes over time, Nadia's desire starts being projected to someone else. Women may have a sexual orientation but it can be fluid. "Women do, in fact, have a general sexual orientation: most are predominantly attracted to men; some are attracted to both sexes; and some are mainly attracted to women. As noted, there are many possible causes of these orientations, and they might unfold at various points in development." (Diamond, 2009, p. 84) As the continuum of heterosexuality does not fit with her conveniently, she seeks pleasure from a girl. The girl from Mykonos is her immediate past while she is in London. That's why she finds comfort thinking her in her dream. "One night as Nadia slept on their cot beside Saeed she had a dream, a dream of the girl from Mykonos, and she dreamt that she had returned to the house they had first arrived in London and had gone upstairs and passed back through the door to the Greek isle, and when Nadia woke she was almost panting, and felt her body alive, or alarmed, regardless changed, for the dream had seemed so real, and after that she found herself thinking of Mykonos from time to time." (Hamid, 2017, pp. 169-70) This incident should not be considered as other from mainstream sexual preference. In an interview taken by Lisa M. Diamond (2009), she found "Diedre has never understood sexual categorization. She explains that she becomes attracted to a person's soul, and does not consider their biological sex. She has had satisfying relationships with both men and women and has no idea who she might settle down with in the future. She has trouble relating to the concept of bisexuality because it emphasizes the existence of two genders, which she finds irrelevant to her own sexuality." (p. 93) So did happen with many other women, she took interview.

Homosexuality gets some attention from the narrator of the novel. Nadia witnesses a kiss scene of a gay couple as if it reflects the inner desire of her. As in the novel, "She was also, not long after, and to her considerable surprise, a witness to their very first kiss, which she captured, without expecting to, through the lens of her camera, and then deleted, later that night, in a gesture of uncharacteristic sentimentality and respect." (Hamid, 2017, p. 175) To the understanding of Sexual Fluidity, Diamond (2009) says, "Women also possess a capacity for fluidity. Think of this as a sensitivity to situations and relationships that might facilitate erotic feelings. An example might be an intense emotional relationship (with either a man or a woman) or exposure to environments that provide positive experiences with same-sex relationships. Fluidity can trigger either same-sex or other-sex attractions." (p. 84) The narrator of the novel creates such a situation through the inclusion of gay kissing scene and it strengthens the possibility of Nadia's fluid attitude to sexuality.

The inclusion of homosexuality bids farewell the heterosexual attraction prevalent between Saeed and Nadia. Because of hard toilsome work, Saeed earns a manly physique but that no longer attracts Nadia. "To Nadia, Saeed was if anything more handsome than he had been before, his hard work and his gauntness suiting him, giving him a contemplative air, making out of his boyishness a man of substance. She noticed other women looking at him from time to time, and yet she herself felt strangely unmoved by his handsomeness, as though he were a rock or a house, something she might admire but without any real desire." (Hamid, 2017, p. 186) Saeed still aspires Nadia's beauty but the coldness from Nadia's side makes the 
relationship standstill. The experience with the volunteer girl in Mykonos and, now, this oscillation of attraction between Nadia and Saeed strengthen the idea "sexual attraction is far more complex than biology allows, and it can be more fully understood by focusing on what people themselves think and do-how they recognize and act on their desires." (Weinberg, Williams and Pryor, 1994, p. 5)

"Saeed made it a point to smile with Nadia, at least sometimes, and he hoped she would feel something warm and caring when he smiled, but what she felt was sorrow and the sense that they were better than this, and that together they had to find a way out. (Hamid, 2017, p. 188) As a result the separation becomes a matter of time only. Except a few occasions, they mostly stay apart. "Nadia once brought to take puff from some weed she got from a co-worker but she was confused how Saeed would react, though finally they did have it together." (Hamid, 2017, p. 193) This trivial sharing of weed puff gives them joy for a time being and they go back to past for reminiscing. It takes them to sexual promiscuity as well. From here it can be said in the words of Rich, "women are 'innately sexually oriented' toward men, or the lesbian choice is simply an acting-out of bitterness toward men, are by no means theirs alone." (Rich, 1980, p. 632) But it also does not assure any dominant sexual preference rather leads us to sexual fluidity.

It's interesting to contemplate that Nadia though is not aroused by Saeed but she is attracted by other men she meets even in street. A kind of bisexual trait we get for the first time in the narrative. As in the novel, "It was not that her sensuality, her sense of the erotic, had died. She found herself aroused readily, by a beautiful man she passed as she walked down to work, by memories of the musician who had been her first lover, by thoughts of the girl from Mykonos. And sometimes when Saeed was out or asleep she pleasured herself she thought increasingly of that girl, the girl from Mykonos, and the strength of her response no longer surprised her.'(Hamid, 2017, p. 199) So Nadia has the sensitivity to be aroused by both sexes what turns into so important in the study of her sexual fluidity.

Saeed and Nadia at last mutually get separated. Meanwhile Nadia seeks for a permanent relationship with a woman, she has found in her workplace. "Different types of music gathered different tribes of people, tribes that had not existed before, as is always the case, and at one such gathering, Nadia saw the head cook from the cooperative, a handsome woman with strong arms, and this woman saw Nadia seeing her and nodded in recognition." (Hamid, 2017, p. 216) The woman's powerful gaze evokes thrilling feeling to Nadia. As in the novel, "But when they (the eyes of the cook) looked at you there was no doubt that they saw, for this woman gazed so powerfully, she was such a watcher, that her watching hit you like a physical force, and Nadia felt a thrill being seen by her, and seeing her in turn." (Hamid, 2017, p. 217) Nadia soon get involved with the cook physically. "Nadia had never before delighted in tasting as she did in the company of the cook, who reminded her a bit of a cowboy, and who made love, when they made love, with a steady hand and a sure eye and a mouth that did little but did it so very well." (Hamid, 2017, p. 217)

The then life of the couple in the novel is questioning. Saeed passes a happy life with the daughter of the preacher, one of the key characters Saeed meets in San Francisco. Nadia's new life with the cook is not described much in the novel but it can be predicted that it was going well. But, surprisingly both Nadia and Saeed miss each other after their separation. As in the text, "Sometimes after they met Nadia would feel part of herself torn inside, and sometimes Saeed would feel this, and both teetered on the cusp of making some physical gesture that would bind them each other again, but both in the end managed to resist." (Hamid, 2017, p. 221)

The way the novel ends that is also so interesting. Saeed comes back to his own country with the daughter of the preacher. Nadia get settled in abroad. But Nadia's long established homosexuality is again questioned. For mental satisfaction she comes back to her home country and meets Saeed. "Half a century later Nadia returned for the first time to the city of her birth, where the fires she had witnessed in her youth and had burned themselves out long ago, the lives of cities being far more persistent and more gently cyclical than those of people, and the city she found herself in was not a heaven but it was not a hell, and it was familiar but also unfamiliar, and as she wandered about slowly, exploring, she was informed of the proximity of Saeed, and after standing motionless for a considerable moment she communicated with him, and they agreed to meet." (Hamid, 2017, p. 227)The situation is too emotional. It rekindles the trait of bisexuality into Nadia. The last scene also showcases some reasons of their misunderstanding. Emotional attachment becomes more important to sexual fluidity at this stage. The narrator says, "Their conversation navigated two lives, with vital details highlighted and excluded, and it was also a dance, for they were former lovers, and they had not wounded each other so deeply as to have lost their ability to find a rhythm together, and they grew younger and more playful as the coffee in their cups diminished, and Nadia said imagine how different life would be if I had agreed to marry you, and Saeed said imagine how different it would be if I had agreed to have sex with you, and Nadia said we were having sex, and Saeed considered and smiled and said yes I suppose we were." (Hamid, 2017, p. 228) The novel ends through their promise of watching the deserts of Chile together which is more than a beautiful moment, can be imagined. "They finished their coffees. Nadia asked if Saeed had been to the deserts of Chile and seen the stars and was it all he had imagined it would be. He nodded and said if she had an evening free he would take her, it was a sight worth seeing in this life, and she shut her eyes and said she would like that very much, and they rose and embraced and parted and did not know, then, if that evening would ever come." (Hamid, 2017, pp. 228-29) This may happen if Nadia's sexuality is fluid. "The sexual attractions triggered by fluidity may be temporary or long-lasting, depending on how consistently a woman encounters the facilitating factors. For example, a heterosexual woman who becomes unexpectedly involved with a close same-sex friend might experience her newfound same-sex attractions as longlasting if the relationship develops into a stable, long term bond. Alternatively, the attractions might disappear altogether if the relationship dissolves. The key point is that the attractions triggered by fluidity do not alter a woman's basic orientation, 
though they might function like an orientation in terms of consistency." (Diamond, 2009, pp. 84-85) Thus Saeed though is proved consistent as heterosexual from the beginning of the novel but Nadia's choice of sexuality changes because of different factors and is proved as sexually fluid.

Finally, how fluidity functions can be examined with the case of Nadia. "Female sexual fluidity is made possible by three interrelated phenomena. The first involves the distinction between two different types of sexual desire, which scientists call proceptivity and arousability. Despite the technical sounding terms, the basic ideas are easy to grasp. Proceptivity refers to what we might call "lust" or "libido." It is a relatively automatic, intense, hormone-driven form of sexual motivation. Arousability, in contrast, refers to a person's capacity to become aroused once certain triggers, cues, or situations are encountered. I will argue that sexual orientation is only "coded" into proceptivity, whereas arousability is an intrinsically more flexible system. I will also show that arousability has a greater day-to-day influence on female sexual desire than on male sexual desire, for reasons having to do with women's hormonal cycles. When considered together, these factors suggest that women's day-to-day sexual desires should be more flexible and fluid than men's." (Diamond, 2009, p. 202) In early life of Nadia, proceptivity drives her heterosexual desire, can be said. She mostly was attracted to her first lover, the musician and later with Saeed where heterosexual sexual orientation has played a key role. Other than 'lust' or 'libido', Nadia got attracted to two women- the girl from Mykonos and the cook in San Francisco. In this case, certain situations typically played the major role. So, 'Arousability' was the reason for falling into love with those women character, can be said.

"The second phenomenon involved in female sexual fluidity is the "unorientation" of romantic love. Although we commonly assume that sexual orientation directs people's romantic feelings along the same lines as their sexual desires, this is not the case. Rather, what we know about the evolutionary origins and neurobiological mechanisms of romantic love suggests that it (1) functions independent of sexual desire, with different biological underpinnings; (2) can develop even in the absence of sexual desire; and (3) does not have an "orientation" in the same way that sexuality does. As a result of these features, we can fall in love with someone without being attracted to him or her, even if that person is the wrong gender for our sexual orientation." (Diamond, 2009, p. 202) This can be attributed to Nadia as her female sex attraction not necessarily drives from any sexual pleasure rather the mental gap and situational experiences perhaps drive her. So her desire actually was functions independent to some extent. And, as the author of Sexual Fluidity claims Nadia's desire of homosexuality could develop in the absence of her sexual desire and certainly, for this reason, it did not have an 'orientation' as sexuality does.

"The third phenomenon involved in female sexual fluidity is the connection between romantic love and sexual desire. This connection makes it possible to start out with strong platonic (that is, nonsexual) feelings of love for another person, and sometimes develop new and unexpected sexual desires for that person as a result. This occurs because love and desire, despite being separate processes, nonetheless have strong cultural, psychological, and neurobiological links between them. One experience can facilitate the other. We are all aware that sexual desire can develop into romantic love, but the opposite can also occur: romantic love can lead to sexual desire." (Diamond, 2009, p. 203) From this quotation it can be well perceived that even if Nadia does have romantic attraction for the two women, that later is merged with her sexual desire. That is why her connection with the two, especially with the cook starts out with strong platonic feeling of love. The vice versa was also possible for pertinent reasons.

\section{Conclusion}

Sexual Fluidity for Nadia seems so inevitable for its close association with Diamond's discussion of 'Sexual Fluidity'. Examining her relationships with the connection between love and desire, it can be said her development of sexual desire for the girl from Mykonos and the cook seems with "wrong gender". This atypical desire of Nadia was restricted to two special relationships. But surprisingly the relationship with the cook possibly lasted for almost a life time. In the case of Saeed it did not happen for a single time. So this kind of involvement may be more evident amongst women than amongst men as there is ample evidence that the cultural, biological, and psychological pathways leading from love to desire are more robust among women.

\section{References}

Beauvoir, S.D., Borde, C., and Malovany-Chevallier, S. (2010). The Second Sex. 1st American ed. New York: Alfred A. Knopf.

Budd, S. (2005). The Psychogenesis of a Case of Female Homosexuality. In Perelbarg, R.J. (Eds.), Freud: A Modern Reader (p. 234). London and Philadelphia: Whurr Publishers Ltd.

Diamond, L. M. (2009). Sexual Fluidity: Understanding Women's Love and Desire. Cambridge, Mass: Harvard University Press.

Hamid, M. (2017) Exit West: A Novel. Riverhead Books, 2017.

Kitzinger, Celia. (1987) The Social Construction of Lesbianism. Reprinted 1995. Sage Publications Ltd.

Rich, A. (1980) "Compulsory Heterosexuality and Lesbian Existence", Signs, Vol. 5, No. 4, Women: Sex and Sexuality (Summer), pp. 631-66, The University of Chicago Press. Online. Stable URL: http://www.jstor.org/stable/3173834

Tyson, L. (2006) Critical Theory Today: A User-Friendly Guide. Second ed. Routledge. 
Weinberg, M. S., Williams, C. J., and Pryor, D. W. (1994) Dual Attraction_Understanding Bisexuality. Oxford University Press. 